\title{
ハードディスクドライブ用磁気センサー応用を 目指したホイスラー合金 CPP-GMR 素子の研究
}

\author{
中谷友也苗) 高橋有紀子炎) 古林孝夫炎) 宝野和 博**
}

1. は じめに

ハードディスクドライブ(hard disk drive, HDD)は, ハー ド磁性体をナノスケールで分散させた磁気記録媒体中の粒子 の磁化状態によりデジタル情報を記録する装置であり, コン ピュータやテレビ, カーナビなどさまざまな電子機器で使わ れている. 全世界のデジタル情報は莫大な量であり, それら の多くはデータセンサーの HDD に蓄えられている，HDD の世界の総出荷は 2010 年で6.5億台であったが，2013年には 7.7 億台に増加すると見られており (1), 単純計算ではそれら の全世界での消費電力は $10^{10} \mathrm{~W}$ のオーダーであると考えら れる†. HDDの記録密度が高くなればデータストレージのた めのエネルギー消費を削減できるため, HDD の高密度化は 重要な技術課題である。2012年現在市販されている HDD の 面記録密度は最大 740 ギガビット/平方インチ $\left(\mathrm{Gbit} / \mathrm{in}^{2}\right)$ に達 している(2)． $1 \mathrm{Tbit} / \mathrm{in}^{2}$ 以上の記録密度の達成には，記録媒 体, 記録へッド, 再生ヘッド，その他の技術に抢いて，磁性 材料をはじめとするさまざまな新材料の開発がカギとなる.

再生ヘッドに使われる磁気センサー(以下, 再生センサー)の 場合, 高磁気抵抗, 低素子抵抗, 高ビット分解能を実現でき るものが必要であり, 電流面直型の巨大磁気抵抗 (currentperperndicular-to-plane giant magnetoresistance, CPPGMR)素子が有望であると考えられている(3).

本稿では, 過去数年間にわたって我々をはじめ国内外の研 究グループで行われている, 高スピン分極ホイスラー合金を 用いた CPP-GMR 素子の研究の現状と, その近隣の技術に ついて概観し, 今後の課題について議論する.

\section{HDD 再生磁気センサーに要求される特性}

再生センサーには歴史的に, 磁気誘導, 異方性磁気抵抗 (AMR), 面内電流巨大磁気抵抗 (CIP-GMR), トンネル磁 気抵抗 (TMR)が用いられてきたが，1990年代後半に実用化 された CIP-GMRへッド以降, スピンバルブ構造 ${ }^{(4)}$ が用い られている. 図1にスピンバルブ構造を有する CPP 型の再 生センサーの模式図を示す，これは一方の強磁性層の磁化方 向が隣接する反強磁性層 ( $\mathrm{IrMn}$ など)の交換バイアスによっ て常に一方向に固定されて打り (固定層), 金属スペーサー層 (GMR の場合)または絶縁体バリア層(TMR の場合)をはさ んで, もう一つの強磁性層(自由層)を積層した構造を持つ. 固定層の磁化は記録媒体に対し垂直方向に固定されており, 記録媒体からの漏洩磁場により自由層の磁化が回転すること で，センサー素子の抵抗が変化する．また素子の積層方向の 上下は軟磁性材料(現在は $\mathrm{NiFe}$ 合金) からなる磁気シールド 層に挟まれており,これはセンサ一素子のリード電極の役割 を担うとともに，隣接する磁気ビットからの漏洩磁場をシー ルドするそれゆえ，シールド層の間隔(シールド間ギャッ プ)が磁気ビットの再生分解能を決定する.

超高密度 HDD 用再生ヘッドの磁気センサー素子として要 求される特性は, (1)高磁気抵抗出力, (2)低素子抵抗 $\times$ 面積値 $(R A)$, 抢よび(3)高再生分解能である。まず，センサーの出 力は磁気抵抗比 $(\Delta R / R)$ と印加バイアス電圧 $\left(V_{\text {bias }}\right)$ の積 $($ 同 様に，抵抗変化値 $\times$ 素子面積 $(\Delta R A)$ とバイアス電流密度 $(J)$ の積)で表される電圧であることから, 高い磁気抵抗効果の みならず，高いバイアス電圧抢よび電流を印加できる素子を

* 独立行政法人物質・材料研究機構 磁性材料ユニット；1)ポスドク研究員 (現在, HGST, a Western Digital company) (テ305-0047 つ くば市千現 1-2-1） 2 ) 主幹研究員 3) 主席研究員

** 独立行政法人物質・材料研究機構 フェロー・磁性材料ユニット長

Study on CPP-GMR with Heusler Alloys for Magnetic Read Sensors of Hard Disk Drives; Tomoya Nakatani*, Yukiko Takahashi*, Takao Furubayashi*, Kazuhiro Hono*(*,**Magnetic Materials Unit, National Institute for Materials Science, Tsukuba)

Keywords: CPP-GMR (current-perpendicular-to-plane giant magnetoresistance), Heusler alloys, hard disk drive, read sensor, TMR (tunnel magnetoresistance) spin-valve, trilayer sensor, lateral spin-valve

† 3.5 インチ HDD 1 台あたりの消費電力は $10 \mathrm{~W}$ 程度であり，全世界の HDD の総数が 10 億台以上とした. 実際のデータセンターでは，サ 一バーコンピュータやそれらの冷却にさらに多くの電力が消費される. また, 最大級の原子炉 1 基の発電出力は $1 \mathrm{GW}$ 程度である. 2012年 9 月 14 日受理 


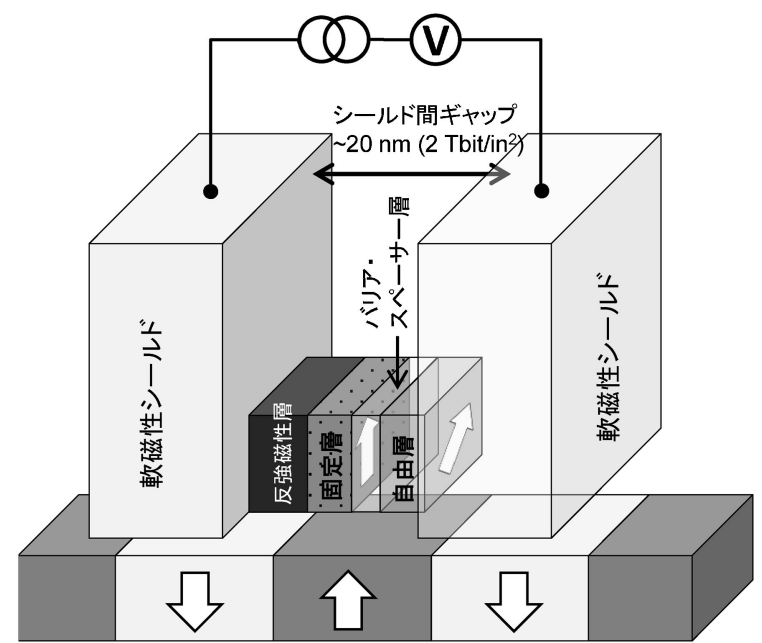

図 1 スピンバルブ構造を有する CPP 型再生センサーと記録 媒体の配置の模式図. 再生センサーの積層構造から下地層抢よ びキャップ層は省略されている. CPP-GMR 素子の場合, 各 層の典型的な膜厚は反強磁性層 $7 \mathrm{~nm}$, 固定層抢よび自由層 5 nm以下，スペーサー層 3-5 nm である(26). 現行の HDD にお けるシールド間ギャップは $30 \mathrm{~nm}$ 程度であるが， $2 \mathrm{Tbit} / \mathrm{in}^{2}$ の 記録密度に相当する再生分解能を得るには, $20 \mathrm{~nm}$ 程度のシー ルド間ギャップが必要であると考えられている(5).

実現する必要がある，低素子抵抗は，抵抗ノイズの低減，高 周波特性抢よびプリアンプとのインピーダンス整合の点から 重要となる。CPP 型再生センサーの場合，記録密度が高い ほど抵抗值は増大するので，より低いRAのセンサーが要求 される．また，上記のように再生分解能はシールド間ギャッ プで決まるため，いかにセンサー素子のトータルの膜厚を薄 くするかが重要となる.

図 2 は東芝の高岸らによって示された， $2 \mathrm{Tbit} / \mathrm{in}^{2}$ の再生 センサーに要求される $R A$ と MR 比である(5). $R A=0.1 \Omega$. $\mu \mathrm{m}^{2}$ より高 $R A$ 側で要求 $\mathrm{MR}$ 比が増大しているが, これは 高 $R A$ 素子に抢ける抵抗ノイズの増大による。一方，低 $R A$ 側でも要求 $\mathrm{MR}$ 比が増大しているが，これは要求される $\Delta R A\left(=R A \times \mathrm{MR}\right.$ 比) がほぼ一定 $\left(20 \mathrm{~m} \Omega \cdot \mu \mathrm{m}^{2}\right.$ 程度 $)$ である ことを示している．また総素子膜厚 (=シールド間ギャップ) は $20 \mathrm{~nm}$ 程度であることが必要である ${ }^{(5)}$. 現在の再生セン サーには, $\mathrm{CoFeB} / \mathrm{MgO} / \mathrm{CoFeB} に$ 抢ける, コヒーレントト ンネル効果 ${ }^{(6)(7)}$ を利用した TMR 素子が使われている( ${ }^{(8)}$ 。 キ ヤノンアネルバと産総研による最近の報告によれば， $R A=$ $1 \Omega \cdot \mu \mathrm{m}^{2}$ で最高 $170 \%$ も TMR 比を達成している ${ }^{(9)}$.この 時の $\mathrm{MgO}$ バリア厚さは $1.05 \mathrm{~nm}$ である。しかしながら，よ り低 $R A$ 領域ではピンホールなどの欠陥により急激に TMR 比は減少し, $R A=0.2 \Omega \cdot \mu \mathrm{m}^{2}$ の素子の TMR 比はわずかに $6 \%$ ある。この TMR 素子の $R A$ と MR 比の関係を図 2 に 示すが，TMR 素子を用いて $2 \mathrm{Tbit} / \mathrm{in}^{2}$ 級 HDD に要求され る低 $R A$ 素子を実現することは極めて困難であるといえよ う。一方, 強磁性金属/非磁性金属/強磁性金属からなる CPP-GMR 素子では $R A=0.05 \Omega \cdot \mu \mathrm{m}^{2}$ 程度の低 $R A$ は容易 に達成されるが, $\mathrm{CoFe}, \mathrm{NiFe}$ など従来の強磁性材料を使っ た場合，得られる $\Delta R A$ は $1 \mathrm{~m} \Omega \cdot \mu \mathrm{m}^{2}$ 以下， MR 比は $2 \%$ 程 度(10) と再生センサーには不十分な值であり，より高い MR 值を示す材料の開発が求められる.

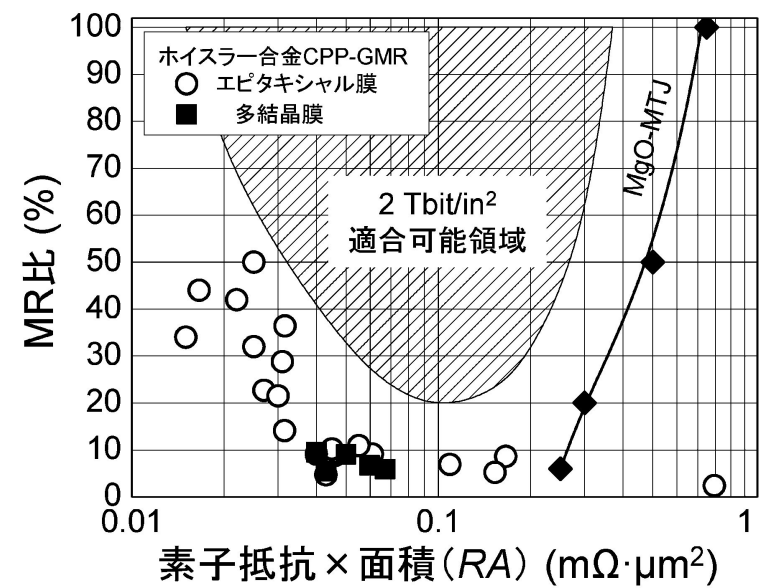

図 2 シミュレーションで予測された $2 \mathrm{Tbit} / \mathrm{in}^{2} \mathrm{HDD}$ 用再生 センサーに要求される抵抗 $\times$ 面積 $(R A)$ 值と $\mathrm{MR}$ 比 ${ }^{(5)}$, および 現在までに報告されている $\mathrm{MgO}-\mathrm{TMR}$ 素子とホイスラー合金 $\mathrm{CPP}-\mathrm{GMR}$ 素子の $R A$ と MR 比の值.

\section{CPP-GMR の原理と高スピン分極材料}

CPP-GMR は強磁性/非磁性/強磁性の 3 層をたは多層構 造に抢ける，スピンの向きに依存した電子の散乱頻度の違い による磁気抵抗効果である。詳しくは解説(11)(12)をご参照い ただきたい、スピン依存散乱には 2 種類あり，強磁性層中 での散乱(バルク散乱) と強磁性層と非磁性スペーサー層の界 面での散乱 (界面散乱)の両方が CPP-GMR に寄与する。こ こでスピン依存の大きさの程度しめす量をスピン非対称性係 数と呼び，スピン分極率を表す。バルク散乱抢よび界面散乱 のスピン非対称性係数はそれぞれ $\beta=\left(\rho_{\downarrow}-\rho_{\uparrow}\right) /\left(\rho_{\uparrow}+\rho_{\downarrow}\right)$, $\gamma\left(R_{\downarrow}-R_{\uparrow}\right) /\left(R_{\uparrow}+R_{\downarrow}\right)$ で定義される。ここで， $\rho_{\uparrow} ， \rho_{\downarrow}$ はそ れぞれ強磁性体のアップスピン・ダウンスピン電子のそれぞ れの抵抗率であり， $R_{\uparrow}, R_{\downarrow}$ は強磁性/非磁性スペーサーな らびに強磁性/非磁性リード電極のアップスピン・ダウンス ピン電子のそれぞれの界面抵抗である。CPP-GMRの大き さを表す量は, MR 比よりも抵抗変化値と素子の面積の積 $(\Delta R A)$ が本質的であり，Valet と Fertのモデルによれば, 近似的に

$$
\Delta R A \approx 2 \rho_{\mathrm{F}} \frac{\beta^{2}}{1-\beta^{2}} t_{\mathrm{F}}+4 A R_{\mathrm{F} / \mathrm{N}} \frac{\gamma^{2}}{1-\gamma^{2}}
$$

という式で表される(13)。ここで， $\rho_{\mathrm{F}}$ は強磁性層の抵抗率, $t_{\mathrm{F}}$ は強磁性層の膜厚, $A R_{\mathrm{F} / \mathrm{N}}$ は強磁性/非磁性界面での抵抗 $\times$ 面積の積である.この式から $\Delta R A$ は強磁性層の膜厚の増 大とともに増加することがわかる。これはバルク散乱の寄与 が強磁性層膜厚に比例することによる。しかしあとで示すよ うに, 実際には $\Delta R A$ は強磁性層膜厚の増加とともに無限に 増大するわけではなく, せいぜい数 $\mathrm{nm}$ から数 $10 \mathrm{~nm}$ の範 囲で飽和する。これは強磁性体中でのスピン緩和によるもの であり，スピン拡散長という量で表される。強磁性体のスピ ン拡散長の報告值は低温で Co が $60 \mathrm{~nm}$ 程度, $\mathrm{Fe}$ が $9 \mathrm{~nm}$ 程度, $\mathrm{Ni}$ が $20 \mathrm{~nm}$ 程度であり，またこれらの元素からなる 合金のスピン拡散長は，大まかにその抵抗率に反比例するこ 
とが経験的に知られている(13)(14). 一般に非磁性体のスピン 拡散長は強磁性体に比べて長く，スペーサー層として使われ る $\mathrm{Cu}$ や $\mathrm{Ag}$ の場合数 $100 \mathrm{~nm}$ 以上である(11)(14). CPP GMR 構造において $\beta, \gamma$, およびスピン拡散長を実験的に求 めるには， $\Delta R A$ を強磁性層厚さについてプロットし, Valet と Fert のモデルによりフィッティングすればよい(13)(15) (16).

式 (1) からわかるように CPP-GMR の大きさ $(\Delta R A)$ は強 磁性層中および界面での散乱のスピン非対称性係数によって 決まり，それを決定するものは強磁性体材料のバンド構造, そして強磁性体と非磁性体のバンド構造の整合性である. 前 者はバルク散乱のスピン非対称性 $\beta$, 後者は界面散乱のスピ ン非対称性 $\gamma$ に影響する．それゆえスピン分極率の高い強磁 性材料を用いることと, またバンド整合の観点から適切なス ペーサー層材料を選択することが，高い CPP-GMR を実現 するための中心的課題である. また, 式 (1)より強磁性体 の抵抗が大きいほど $\Delta R A$ が大きくなることがわかる. 従来 CPP-GMR 材料として使用されてきた $\mathrm{CoFe}$ 合金 (主に $\mathrm{Co}_{50}$ $\mathrm{Fe}_{50}$ 組成が使用される)では $\beta$ は 0.7 程度の比較的高い值を示 すが(14), 抵抗率は $10 \mu \Omega \cdot \mathrm{cm}$ 程度と小さいため, $\Delta R A$ は 1 $\mathrm{m} \Omega \cdot \mu \mathrm{m}^{2}$ 程度の值しか得られなかった ${ }^{(10)}$ 。そこで CoFe に 対し第 3 元素を添加することによって抵抗率を上げ，高い CPP-GMR を得る試みが行われてきた。 多くの場合, 抵抗 率の増加とともに $\beta$ は低下してしまう傾向があるが，Co$\mathrm{Fe}-\mathrm{Al}$ 系(17)(18) や $\mathrm{Co}-\mathrm{Fe}-\mathrm{Ge}$ 系 ${ }^{(19)}$ では比較的高い $\beta$ を保っ たまを高い抵抗率が得られ， $\mathrm{CoFe}$ に比べて 2 倍程度大きな CPP-GMR が得られている.

最近, $\mathrm{L} 2_{1}$ 構造を持つ $\mathrm{Co}$ 基のホイスラー合金 $\left(\mathrm{Co}_{2} \mathrm{YZ}\right)$ が 高いスピン分極率を持つ強磁性材料として注目されている. これらはバンド計算によりハーフメタルであると予測された 強磁性体である ${ }^{(20)(21)}$. ハールメタルは図 3 に示すようにフ ェルミ準位近傍において片方のスピン電子の状態しか存在し ない金属のことであり，伝導電子が完全にスピン分極してい るために， $\beta$ および $\gamma$ はいずれも 1 となると予想され，大き な CPP-GMR を示すことが期待される. ハーフメタルとし てさまざまな材料が理論的に予言されているが，Co 基の小 イスラー合金は，その高いキュリー温度や結晶構造の安定性

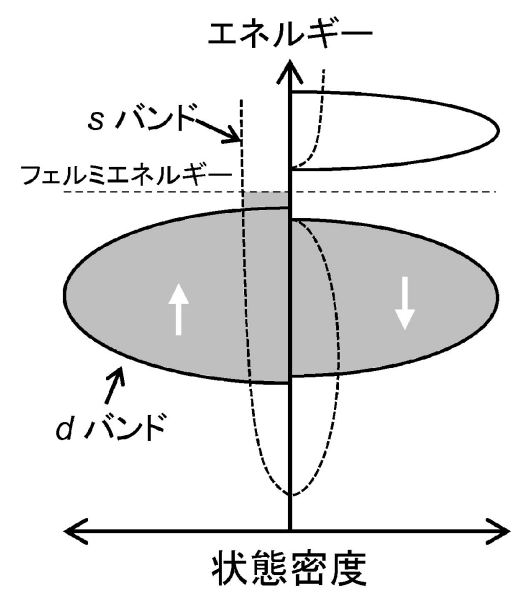

図 3 ハーフメタルのバンド構造. フェルミエネルギー付近に おいてアップスピンは電子状態をもつが，ダウンスピンはバン ドギャップをもつ.
の観点から，もっとも実現の可能性の高いハーフメタルとし て注目されている. ホイスラー合金は L $22_{1}$ 構造を安定相に もつ 3 元系の規則合金であり，代表的なものに $\mathrm{Co}_{2} \mathrm{MnSi} や$ $\mathrm{Co}_{2} \mathrm{FeSi}$ などが知られている。ごく低温においてであるが, $\mathrm{Co}_{2} \mathrm{MnSi}$ を用いた TMR 素子に扔いてそのハーフメタル性 が実証されている(22)(23).

ホイスラー合金の $\mathrm{L} 22_{1}$ 規則度の乱れはハーフメタル性を 失わせ，スピン分極率の低下を引き起こす(24)(25)。そのた め，高いスピン分極率を実現するには，デバイスに用いられ る強磁性体薄膜において，いかに $\mathrm{L} 22_{1}$ 規則度の高いホイス ラー合金を作製するかということに尽きる．スパッタリング 法をはじめとする真空成膜法で作製されたホイスラー合金薄 膜は， A2 構造や B2 構造のように規則度の低い状態とな り，規則度の向上のために熱処理を行う必要がある. 熱処理 は薄膜界面での相互拡散をはじめ CPP-GMR 素子の特性の 劣化につながるので, あまり高い温度は好ましくなく, 本稿 で取り扱うエピタキシャル膜の場合, $500^{\circ} \mathrm{C}$ 程度が限度であ る。また，多結晶薄膜からなる実際の再生センサーでは，反 強磁性体の交換バイアスや軟磁性シールド層の特性劣化によ り $300^{\circ} \mathrm{C}$ 程度が限度であろう ${ }^{(26)}$. それゆえ，現実のデバイス において高スピン分極率ホイスラー合金薄膜を実現するに は，その作製プロセスの最適化のみならずホイスラー合金材 料の組成の選択がきわめて重要である. 具体的な戦略として は，高い L $22_{1}$ 相の安定度をもつ合金，すなわち規則一不規則 変態 $\left(\mathrm{L} 22_{1}-\mathrm{B}_{2}\right)$ 温度が高く, 規則化の駆動力の大きい合金を 得ること, さらに, 規則度が低くても高いスピン分極率を維 持する合金を得ることがその 2 大柱であると考えられる。

我々のグループでは以前より，ホイスラー合金のバルク試料 を作製し, その熱力学, 磁気, 構造特性を評価し, スピン分 極率を点接触アンドレーエフ反射法によって直接測定する手 法を用いてホイスラー合金の開発に取り組んできた。それら の詳細については過去の解説を参照されたい(27). 以下で は，我々が開発した組成を含む，ホイスラー合金を用いた CPP-GMR 素子に打けるスピン依存伝導特性と構造につい て紹介する.

\section{4. $\mathrm{Co}_{2} \mathrm{Fe}\left(\mathrm{Al}_{0.5} \mathrm{Si}_{0.5}\right)$ ホイスラー合金 $\mathrm{CPP}-\mathrm{GMR}$}

$\mathrm{Co}_{2} \mathrm{Fe}\left(\mathrm{Al}_{0.5} \mathrm{Si}_{0.5}\right)$ ホイスラー合金は (以下 $\left.\mathrm{CFAS}\right)$ は $\mathrm{Al}-\mathrm{O}$

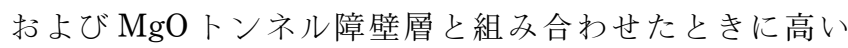
TMR 比を示す材料として知られている(28)(29). 我々は以 前，このCFAS 抢よび $\mathrm{Co}_{2} \mathrm{MnSi}$ 合金を強磁性層に用いた CPP-GMR 素子に拈いて，通常よくスペーサーに用いられ る $\mathrm{Cu}$ にかえて $\mathrm{Ag}$ を用いることで大きな $\mathrm{CPP}-\mathrm{GMR}$ が得 られることを紹介した ${ }^{(30)-(32)}$ 。この理由として, まず面直 に(001)方位をもつエピタキシャルホイスラー合金薄膜と $\mathrm{Cu}$ や $\mathrm{Ag}$ など fcc 構造のスペーサー層の結晶方位関係は, ホイスラー(001)[110]//fcc(001)[100]であり，スペーサー として $\mathrm{Cu}$ を用いた場合，9\%以上の大きな格子ミスマッチ を生ずる．電子顕微鏡観察によれば，この格子ミスマッチに より，5nm 厚さの $\mathrm{Cu}$ スペーサー層中にきわめて高密度の 双晶が形成される ${ }^{(31)(32)}$ 。このため $\mathrm{Cu}$ 中でスピン散乱によ 
り CPP-GMR が減少することが考えられる. 一方, ホイス ラー合金と $\mathrm{Ag}$ の格子ミスマッチは $2 \%$ 以下であり, 以下に 示すように $\mathrm{Ag}$ スペーサー層中に目立った格子欠陥は確認さ れない，また， $\mathrm{Ag}$ は $\mathrm{Co}, \mathrm{Fe}, \mathrm{Si}$ と非固溶であるため界面で の拡散が抑制できると期待される。岩瀬らは $\mathrm{Co}_{2} \mathrm{MnSi}$ と $\mathrm{Ag}$ を用いた CPP-GMR 擬スピンバルブに掞いて室温で $\Delta R A=9 \mathrm{~m} \Omega \cdot \mu \mathrm{m}^{2}, \mathrm{MR}$ 比 $29 \%$ という大きな $\mathrm{CPP}-\mathrm{GMR}$ を 報告した ${ }^{(33)}$. 彼らは $\mathrm{Co}_{2} \mathrm{MnSi}$ と $\mathrm{Ag}$ の界面におけるスピン 依存散乱の寄与が大きいことを示している，我々は，CFAS ホイスラー合金と Ag スペーサー層を用いた CPP-GMR ス ピンバルブに拈いてそのスピン依存散乱を系統的に調査し た ${ }^{(16)(34)}$.

図 4 は $\mathrm{MgO}(001)$ 単結晶基板 $/ \mathrm{Cr}(10 \mathrm{~nm}) / \mathrm{Ag}(100 \mathrm{~nm}) /$ CFAS $(5 \mathrm{~nm}) / \mathrm{Ag}(5 \mathrm{~nm}) / \mathrm{CFAS}(5 \mathrm{~nm}) / \mathrm{Co}_{50} \mathrm{Fe}_{50}(1 \mathrm{~nm}) /$ $\operatorname{IrMn}(10 \mathrm{~nm}) / \mathrm{Ru}(8 \mathrm{~nm})$ 積層膜からなる交換バイアススピ ンバルブ素子の室温に打り CPP-GMR 曲線である ${ }^{(35)}$. $\mathrm{Ag}(100 \mathrm{~nm})$ 層はバッファー層および, CPP-GMR 測定のた めのリード電極としてはたらく. $500^{\circ} \mathrm{C} て ゙ 30$ 分間熱処理した 後, $70 \mathrm{~nm} \times 140 \mathrm{~nm}$ に設計された楕円形の素子に加工した。 $R A$ は $30 \mathrm{~m} \Omega \cdot \mu \mathrm{m}^{2}$ 程度であり,すべて金属膜からなる CPP-GMR スピンバルブとしては典型的な值である. $\Delta R A$ は $6.4 \mathrm{~m} \Omega \cdot \mu \mathrm{m}^{2}, \mathrm{MR}$ 比は $21.5 \%$ と $\mathrm{CoFe} や \mathrm{NiFe}$ など従来 の強磁性材料を用いた CPP-GMR に比べ，5倍以上大きな 值である.これはホイスラー合金の高いスピン分極率に起因 すると考えられる. 交換バイアススピンバルブは一方の強磁 性層の磁化を固定するため, 容易に反平行磁化状態を実現す ることができる.しかし，上で述べたようにV Valet と Fert のモデルを用いてスピン依存伝導特性を解析するには, 強磁 性層膜厚を変化させる必要があるが, 交換バイアススピンバ ルブの場合, 厚い強磁性層の磁化を固定することには限界が あるのでこのような実験には不向きである。そこで我々は IrMn などの反強磁性層を用いずに，2つの強磁性層間の静 磁結合によって反平行磁化状態が得られる擬スピンバルブ構 造を用いて CPP-GMR のスピン依存伝導を評価した(16)(34).

擬スピンバルブ膜の構成は, $\mathrm{MgO}(001)$ 単結晶基板 $/ \mathrm{Cr}$

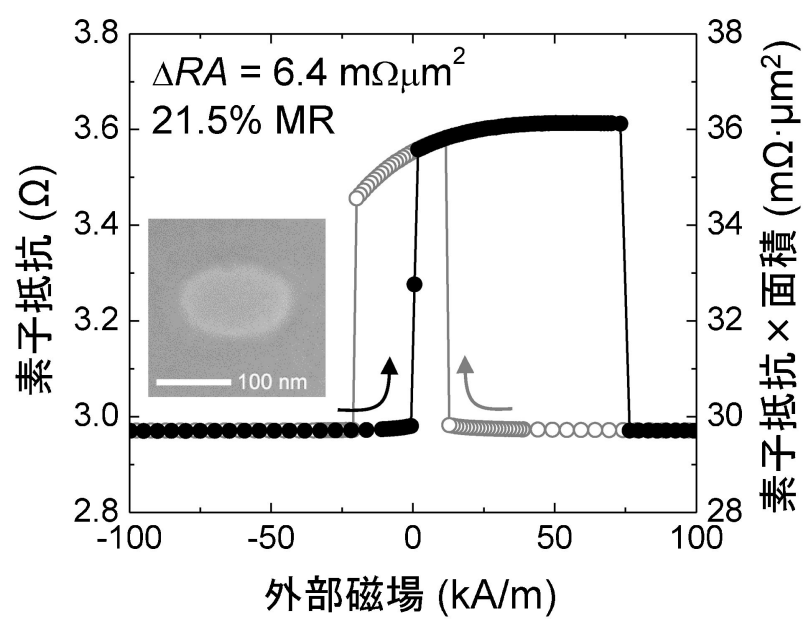

図 4 CFAS $(5 \mathrm{~nm}) / \mathrm{Ag}(5 \mathrm{~nm}) / \mathrm{CFAS}(5 \mathrm{~nm}) / \mathrm{Co}_{50} \mathrm{Fe}_{50}(1$ $\mathrm{nm}) / \operatorname{IrMn}(10 \mathrm{~nm})$ 積層膜からなる CPP-GMR スピンバルブ素 子の室温に抢ける MR 曲線. 挿入図は素子の走査電子顕微鏡像.
$(10 \mathrm{~nm}) / \mathrm{Ag}(100 \mathrm{~nm}) / \mathrm{CFAS}(t \mathrm{~nm}) / \mathrm{Ag}(5 \mathrm{~nm}) / \mathrm{CFAS}$ $(\mathrm{tnm}) / \mathrm{Ag}(5 \mathrm{~nm}) / \mathrm{Ru}(8 \mathrm{~nm})$ であり, $\mathrm{Ag}$ スペーサー層を挟 んだ上下の CFAS 膜厚は等しく, $2.5 \mathrm{~nm}$ から $22 \mathrm{~nm}$ のさま ざまな膜厚のものを作製した. 図 5 (a)に $500^{\circ} \mathrm{C} て ゙ 30$ 分熱処 理された CFAS $(8 \mathrm{~nm}) / \mathrm{Ag}(5 \mathrm{~nm}) / \operatorname{CFAS}(8 \mathrm{~nm})$ 擬スピンバ ルブ膜の断面 TEM 像を示す。きわめて平坦かつシャープな CFAS/Ag 界面が得られている. CFAS 層からのマイクロビ 一ム電子回折図形に見られるように, CFAS 層は B2 構造で あり，L2 1 規則は確認されなかった．また $\mathrm{Cu}$ スペーサーと は異なり(31)(32), $\mathrm{Ag}$ スペーサー中に格子久陥は観察され ず，また CFAS / Ag 界面でのミスフィット転位もわずかし か観察されなかった。これは CFAS/Ag 界面に打ける格子 ミスマッチが $1.7 \%$ とさいことに起因すると考えられる.

図 5 (b)，（c）に低温 $\left(-259^{\circ} \mathrm{C}\right)$ 抢よび室温に抢ける CPPGMR 曲線を示す. $2.5 \mathrm{~nm}$ というきわめて薄い強磁性膜厚に もかかわらず室温で $\Delta R A=5.1 \mathrm{~m} \Omega \cdot \mu \mathrm{m}^{2}, \mathrm{MR}$ 比 $34 \%$ という 大きな $\mathrm{CPP}-\mathrm{GMR}$ を示した。 また低温では $\Delta R A=11.3$ $\mathrm{m} \Omega \cdot \mu \mathrm{m}^{2}, \mathrm{MR}$ 比 $80 \%$ に増加した. 実際の再生センサーでは シールド間ギャップの制約から強磁性層の厚さはそれぞれ数 $\mathrm{nm}$ 程度であることが必要とされるので, $2.5 \mathrm{~nm}$ というきわ めて薄い膜厚で比較的高い CPP-GMR が得られることは応
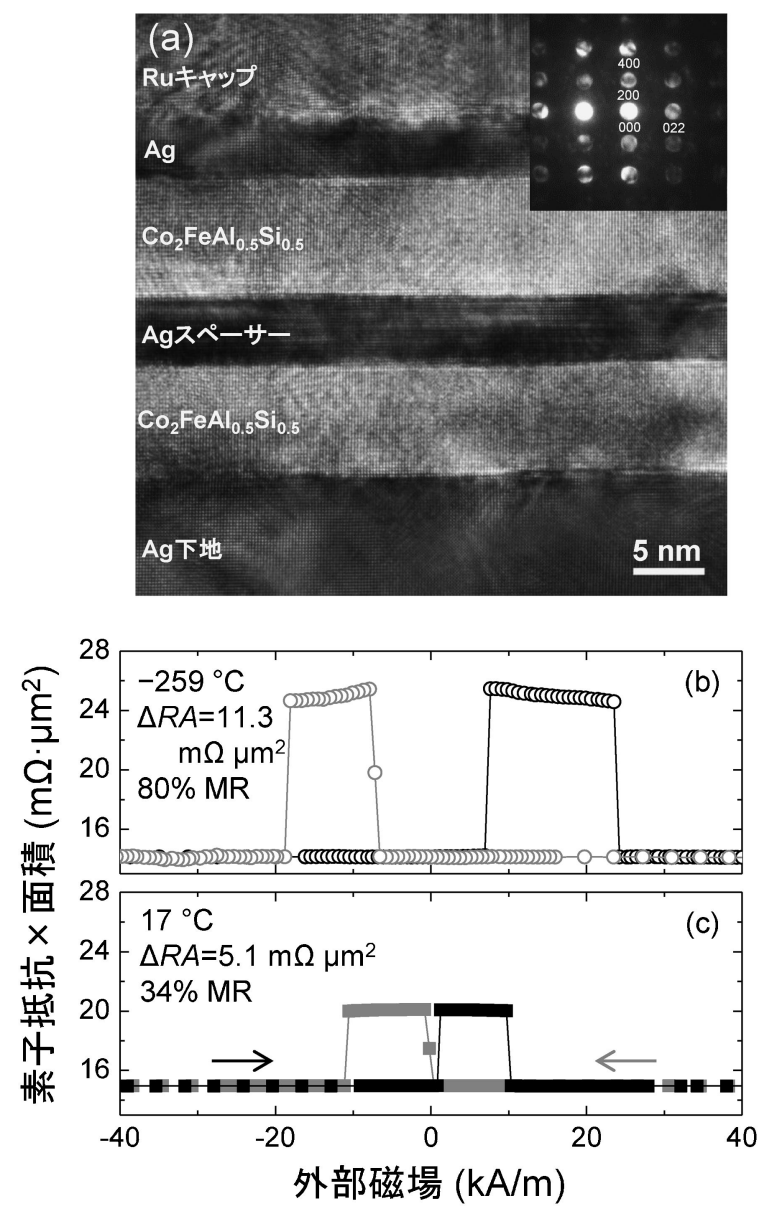

図 5 (a) $\operatorname{CFAS}(8 \mathrm{~nm}) / \operatorname{Ag}(5 \mathrm{~nm}) / \operatorname{CFAS}(8 \mathrm{~nm})$ 積層膜から なる CPP-GMR 擬スピンバルブ膜の断面透過電子顕微鏡およ び CFAS 層からの電子回折図形. $\operatorname{CFAS}(2.5 \mathrm{~nm}) / \mathrm{Ag}(5 \mathrm{~nm}) /$ $\mathrm{CFAS}(2.5 \mathrm{~nm})$ 擬スピンバルブ素子の (b) $-259^{\circ} \mathrm{C}$ (c) $17^{\circ} \mathrm{C}$ 抢ける CPP-GMR 曲線. 


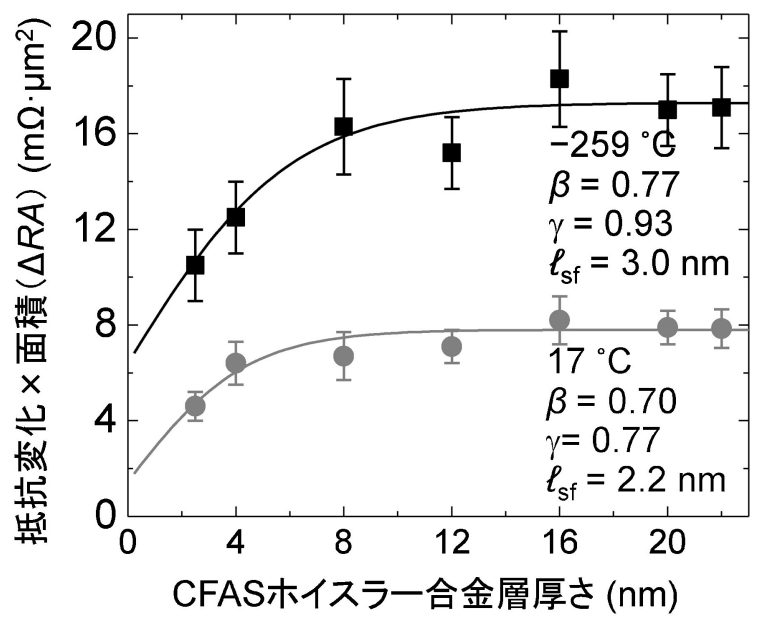

図 $6 \operatorname{CFAS}(t) / \mathrm{Ag}(5 \mathrm{~nm}) / \mathrm{CFAS}(t) \quad(t=2.5-22 \mathrm{~nm})$ 擬スピン バルブ素子の抵抗変化 $\times$ 面積 $(\Delta R A)$ の CFAS 膜厚依存性と Valet-Fert のモデルによるフィッティングによるバルク散乱ス ピン非対称性 $\beta$, 界面散乱スピン非対称性 $\gamma$ および強磁性層の スピン拡散長 $\ell_{\mathrm{sf}}$ の定量評価.

用上有用な特性である.

図 6 にさまざまな CFAS 膜厚に対する $\Delta R A$ の值のプロッ トと Valet-Fert のモデルによるフィッティングを示す．数 $\mathrm{nm}$ 以下の薄い領域においては膜厚の増加とともに $\Delta R A$ が 増加する傾向を示し，これはバルク散乱の寄与が膜厚の増加 とともに増加すること示している。しかしそれ以上の膜厚領 域では $\Delta R A$ はほぼ一定であり, CFAS 中でのスピン拡散長 がこの膜厚の範囲内であることを示している。 また， $t=0$ に外挿した $\Delta R A$ はゼロでない值を示すが，これは界面散乱 の寄与である.フィッティングの結果, バルク散乱スピン非 対称性係数 $\beta$, 界面散乱スピン非対称性係数 $\gamma, \mathrm{CFAS}$ 中で のスピン拡散長 $\ell_{\mathrm{sf}}$ は, 室温で $\beta=0.70, \gamma=0.77, \quad \ell_{\mathrm{sf}}=2.1$ $\mathrm{nm},-259^{\circ} \mathrm{C}$ で $\beta=0.77, \gamma=0.93, \ell_{\mathrm{sf}}=3.0 \mathrm{~nm}$ であった. $\beta$ の値は $\mathrm{CoFe}$ に比べて若干大きい程度であるが，CFAS の抵 抗率は室温で $71 \mu \Omega \cdot \mathrm{cm}$, 低温で $62 \mu \Omega \cdot \mathrm{cm}$ と CoFe と比べ て 6 倍以上大きな值であるので，CFAS は大きなバルク散 乱の寄与を示す，スピン拡散長はきわめて短いが，これは先 に述べたように，スピン拡散長が抵抗率の反比例するという 経験則からすると妥当な值である，また，界面散乱の寄与が 大きくこ机は CFAS $/ \mathrm{Ag}$ の大きな特徵である．界面抵抗の 值は $\mathrm{CFAS} / \mathrm{Ag}$ 多層膜を作製し，そのRA を測定すること で実験的に求めることができるが，その值は $0.25 \mathrm{~m} \Omega \cdot \mu \mathrm{m}^{2}$ と小さい值であった ${ }^{(34)}$ 。これは多数スピンであるアップス ピン電子に対する $\mathrm{CFAS} / \mathrm{Ag}$ 界面抵抗が小さいことを示し ており，アップスピン電子に対する界面でのバンド整合性が よいことに起因すると考えられる，一方，大きな $\gamma$ は，ダウ ンスピン電子の界面抵抗がアップスピン電子よりはるかに大 きいことを示して抢り，これにより界面散乱が CPP-GMR に大きく寄与する．何度も述べているように，薄い強磁性層 を用いて大きな CPP-GMR を得ることが HDD 再生磁気セ ンサーの応用にとって重要であるので，Agスペーサーによ る大きな界面散乱の寄与は重要である。 ホイスラー合金と $\mathrm{Ag}$ スペーサーの大きな界面散乱は， $\mathrm{Co}_{2} \mathrm{MnSi}$ を用いて

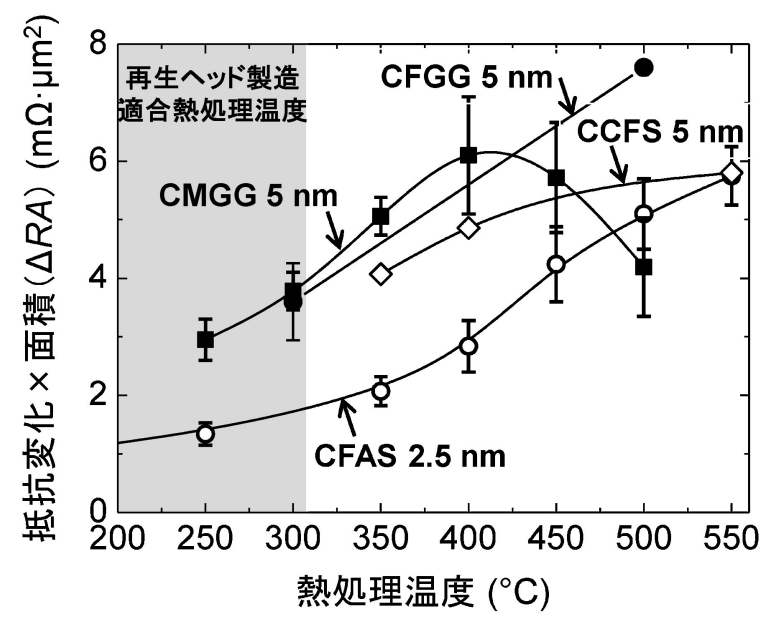

図 7 CFAS, $\mathrm{Co}_{2} \mathrm{Fe}\left(\mathrm{Ga}_{0.5} \mathrm{Ge}_{0.5}\right)(\mathrm{CFGG}), \mathrm{Co}_{2}\left(\mathrm{Cr}_{0.1} \mathrm{Fe}_{0.9}\right) \mathrm{Si}$ (CCFS)，および $\mathrm{Co}_{2} \mathrm{Mn}\left(\mathrm{Ga}_{0.25} \mathrm{Ge}_{0.75}\right)(\mathrm{CMGG})$ ホイスラー合金 を用いた $\mathrm{CPP}-\mathrm{GMR}$ 擬スピンバルブの室温における $\Delta R A$ と 熱処理温度の関係. 灰色の領域は, 現在の再生ヘッド作製プロ セスに適合できると考えられる熱処理温度の領域.

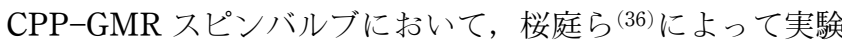
的に，また三浦ら(37)によって理論的に示されており， CFAS に限らず多くのホイスラー合金と Ag スペーサー組み 合わせの共通の特徵かもしれない。以上のことから，Agは ホイスラー合金層との格子整合，拡散に対する高い熱安定 性，そして良好なバンド整合性による界面散乱の CPPGMRへの寄与という点で望ましいスペーサー材料であると 結論できる.

図 7 にCFASをはじめ我々がこれまでに検証したさまざ まなホイスラー合金を用いた $\mathrm{CPP}-\mathrm{GMR}$ 擬スピンバルブに おける $\Delta R A$ の熱処理温度依存性を示す。いずれの合金にお いても熱処理温度の増加とともに $\Delta R A$ は増加し，これはホ イスラー合金の $\mathrm{B} 2$ または $\mathrm{L} 2{ }_{1}$ 規則度の向上に対応している ことがわかっている(35)(38)(39)。ここでは $400^{\circ} \mathrm{C}$ 以上の高温で の熱処理が高い $\Delta R A$ を得るために必要であるが，この温度 は現行の HDD 再生へッドの作製プロセスに適合できる熱処 理温度に比べかなり高い值であり，低温熱処理でも高い規則 度を示す合金の開発が求められる。

\section{5. $\mathrm{Co}_{2} \mathrm{Fe}\left(\mathrm{Ga}_{0.5} \mathrm{Ge}_{0.5}\right)$ ホイスラー合金の開発}

我々のPCAR 法を用いたスピン分極率の直接測定により， $\mathrm{Co}_{2} \mathrm{Fe}\left(\mathrm{Ga}_{0.5} \mathrm{Ge}_{0.5}\right)$ (以下 $\mathrm{CFGG}$ ) 組成のものが有望であるこ とが明らかになった ${ }^{(40)(41)} \cdot \mathrm{Co}_{2} \mathrm{Fe}\left(\mathrm{Ga}_{x} \mathrm{Ge}_{1-x}\right)$ の 4 元系ホイ スラー合金のスピン分極率をPCAR 法により測定したとこ ろ， $x=0.5$ の組成に㧍いてもっとも高いスピン分極率 $P=$ 0.69を示した ${ }^{(40)}$.これは CFASのバルク合金のに打けるス ピン分極率 $P=0.60$ に比べ明らかに高い值であり ${ }^{(42)}, \mathrm{CFGG}$ 薄膜の高スピン分極率材料としての可能性を示している. 図 8 (a) に CFGG $(12 \mathrm{~nm}) / \mathrm{Ag}(5 \mathrm{~nm}) / \mathrm{CFGG}(12 \mathrm{~nm})$ の擬スピ ンバルブ素子の CPP-GMR 曲線を示す．室温で $\Delta R A=9.5$ $\mathrm{m} \Omega \cdot \mu \mathrm{m}^{2}, \mathrm{MR}$ 比 $42 \%$ という高い值を示した。 さらに低温 $-263^{\circ} \mathrm{C}$ では $\Delta R A=26 \mathrm{~m} \Omega \cdot \mu \mathrm{m}^{2}, \mathrm{MR}$ 比 $129 \%$ ときわめて高 
い值であり，CFGG 膜の高いスピン分極率を反映している と考えられる. また CFGG 膜厚を $5 \mathrm{~nm}$ に低減させた素子 に打いても室温で $\Delta R A=7.6 \mathrm{~m} \Omega \cdot \mu \mathrm{m}^{2}, \mathrm{MR}$ 比 $44 \%$, $-263^{\circ} \mathrm{C}$ で $\Delta R A=20 \mathrm{~m} \Omega \cdot \mu \mathrm{m}^{2}, \mathrm{MR}$ 比 $119 \%$ という大きな值 を示した ${ }^{(35)}$ 。前章と同様に Valet-Fert のモデルを用いたス ピン依存伝導特性の解析では, 室温で $\beta=0.73, \gamma=0.60, \ell_{\mathrm{sf}}$ $=2.1 \pm 0.4 \mathrm{~nm},-263^{\circ} \mathrm{C}$ において $\beta=0.90, \gamma=0.84, \ell_{\mathrm{sf}}=1.8$ $\pm 0.4 \mathrm{~nm}^{(43)}$ と PCAR 法によるスピン分極率測定から予想さ れたように, CFAS を用いた場合に比べ高いバルク散乱の寄 与が得られていることがわかる. 図 8(b)に断面 TEM 像を 示すが, 平坦な $\mathrm{CFGG} / \mathrm{Ag}$ 界面が形成されている. 格子定 数の違いによるミスフィット転位は全く観察されない。これ は CFGG/Ag 界面での格子ミスマッチが $0.8 \%$ と非常に小さ いためである. また, 電子回折図形から上下 CFGG ともに $\mathrm{B} 2$ 構造となっている.

以上のように $\mathrm{CFGG}$ と $\mathrm{Ag}$ を使った $\mathrm{CPP}-\mathrm{GMR}$ 素子は CFGGの高いバルク散乱により大きな $\Delta R A$ を実現した. 特 に- $263{ }^{\circ} \mathrm{C}$ では $\beta=0.90$ という極めて大きな值を示し, CFGG が高スピン分極材料として有望であることがわか る. 一方で, $-263^{\circ} \mathrm{C}$ での $\Delta R A$ は室温のそれと比較して約
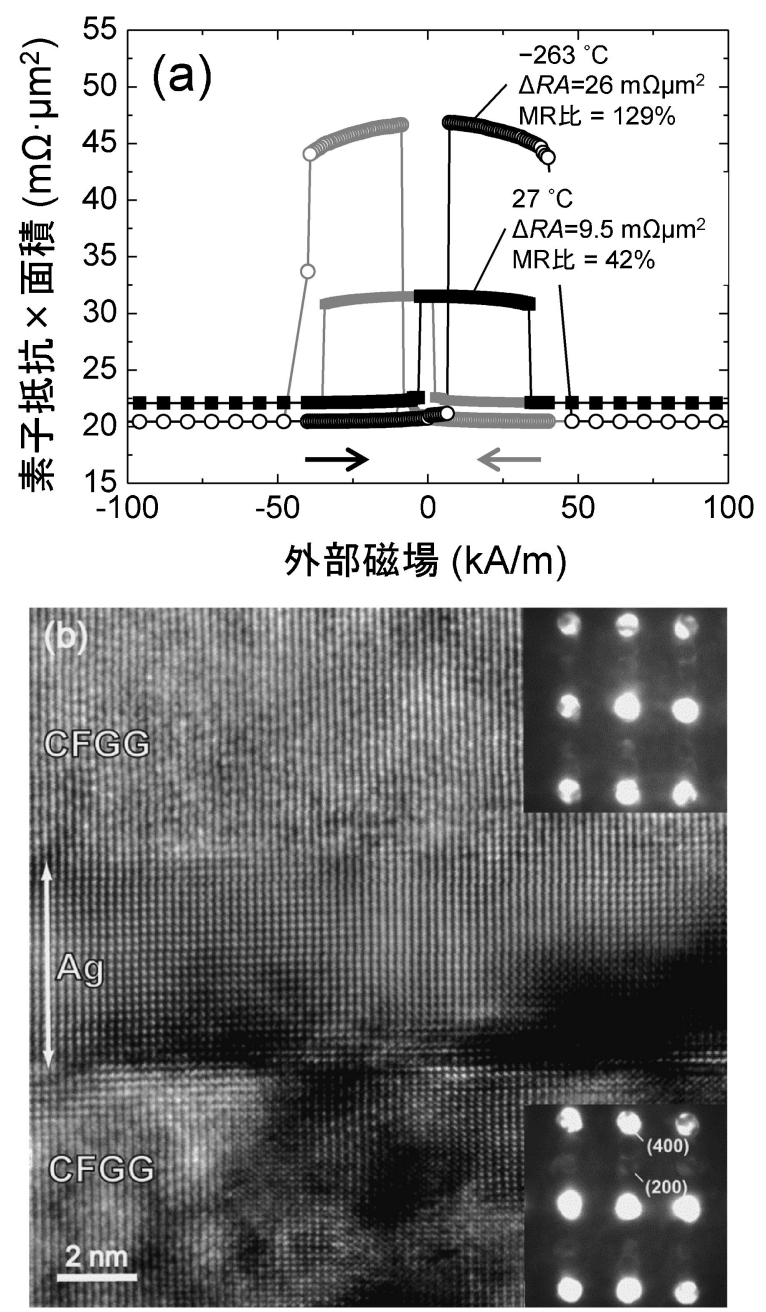

図 8 (a) $\mathrm{CFGG}(12 \mathrm{~nm}) / \mathrm{Ag}(5 \mathrm{~nm}) / \mathrm{CFGG}(12 \mathrm{~nm})$ 擬スピン バルブ素子の $-263^{\circ} \mathrm{C}$ おび $27^{\circ} \mathrm{C} に$ おける $\mathrm{CPP}-\mathrm{GMR}$ 曲線, (b) TEM 像とそれぞれの CFGG 層からの電子回折図形.
2.8倍と非常に大きな温度依存性を示している．このような ホイスラー合金における磁気抵抗の大きな温度依存性は強磁 性トンネル接合でも観測されており (22)(23), 室温で大きな CPP-GMR を実現するにはそのメカニズムの解明が重要で ある。

\section{6. スピンバルブに代わる新しいセンサー素子の開発}

\section{(1) 3 層センサー}

前章までの CPP-GMR 素子はスピンバルブ構造での使用 を想定したものであった．スピンバルブでは反強磁性層を含 むことから, 再生センサー全体の層膜厚すなわちシールド間 ギャップを低減することに限界がある. 2 Tbit/in ${ }^{2}$ の記録密 度に抢けるシールド間ギャップは $20 \mathrm{~nm}$ 程度と予測されて おり(5), これをスピンバルブで達成することは困難であると 思われる. そのような極薄センサーとして, 強磁性/非磁性 スペーサー/強磁性の 3 層構造のみから構成される 3 層セン サー(trilayer sensor) が提案されている(44).これは図 9 に示 すように 2 つ磁性層がいずれもフリー層であり, 外部磁 場によって磁化が対称に回転するものである．それがちょう どハサミの刃の動きに似ていることから scissors sensor と も呼ばれる. 3 層センサーの動作を得るためには, 外部磁場 がない場合に 2 つ磁性層の磁化配列が反平行に安定する ことが重要であり, そのためには磁性層間に反強磁性的な交 換結合が働いていることが必要である．このような反強磁性 層間交換結合は1980年代後半に Grünberg らによって $\mathrm{Fe} / \mathrm{Cr}$ 多層膜によって見出されて以来 ${ }^{(45)}$, 多くの材料系において 観察されているが(46)，不思議なことにホイスラー合金系に おいてはほとんど知られていなかった. われわれは最近, 上 記の $\mathrm{Co}_{2} \mathrm{Fe}\left(\mathrm{Al}_{0.5} \mathrm{Si}_{0.5}\right)$ (CFAS) ホイスラー合金と $\mathrm{Ag}$ をスペ 一サー層に用いた系において, $\mathrm{Ag}$ 膜厚と熱処理温度を最適 化することにより, ホイスラー合金系としては初めて反強磁 性層間交換結合を見出し，3 層センサー動作を確認したので 以下に紹介する(47).

図10(a)に $\mathrm{MgO}(001)$ 単結晶基板上に $\mathrm{Cr}(10 \mathrm{~nm}) / \mathrm{Ag}(100$ $\mathrm{nm})$ 下地層を用いてエピタキシャル成長させた CFAS (5 $\mathrm{nm}) / \mathrm{Ag}(2 \mathrm{~nm}) / \mathrm{CFAS}(3 \mathrm{~nm}) 3$ 層膜の 3 つの熱処理条件に おける磁化曲線を示す。まず未熱処理では，外部磁場がゼロ

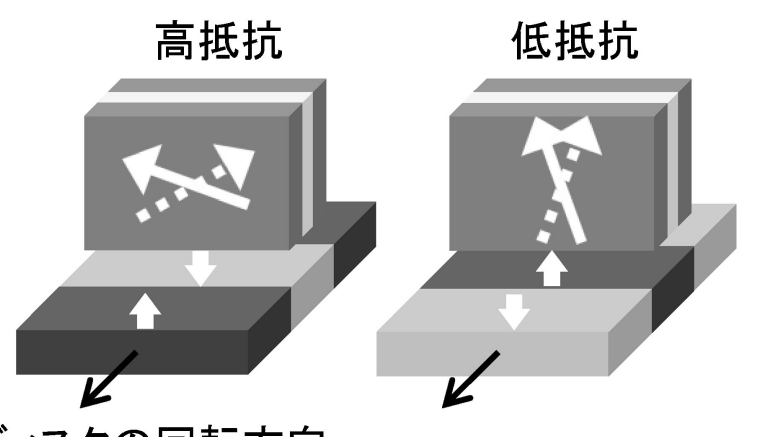
ディスクの回転方向

図 93 層膜センサーの動作原理の模式図. 2 つの強磁性層の いずれもが自由層であり, 記録媒体からの漏洩磁場によって八 サミの刃のように磁化が回転する. 
に打ける磁化(残留磁化) は高磁場に打硠和值(飽和磁化) にほぼ等しい，すなわち強磁性的挙動を示す。一方， $400^{\circ} \mathrm{C}$ で30分熱処理された膜では, 低外部磁場において磁化の減 少が見られ，残留磁化の飽和磁場に対する比はおよそ0.25で あった。これは, 試料の 2 つの CFAS 層の膜厚がそれぞれ $3 \mathrm{~nm}$ 抢よび $5 \mathrm{~nm}$ であることから, ゼ口磁場付近での $2 つ$ の CFAS 薄膜の磁化配列が反平行であることを示している $((5-3) /(5+3)=0.25)$. すなわち, CFAS/Ag/CFAS 3 層 膜において反強磁性層間交換結合が働いている.さらに高い $450^{\circ} \mathrm{C}$ で熱処理された 3 層膜ではさらに明瞭な反強磁性層間 交換結合が見られる。このときの飽和磁場は $40 \mathrm{kA} / \mathrm{m}$ 程度 であり，交換層間結合強度は $J_{1} \sim-0.09 \mathrm{~mJ} / \mathrm{m}^{2}$ であった. また，Agスペーサー層の膜厚を $2.0 \mathrm{~nm}$ から厚くしていく と, $2.6 \mathrm{~nm}$ 付近でいったん反強磁性的な結合が見られなく なり， $3.2 \mathrm{~nm}$ で再び現れる.すなわちスペーサー厚さに対 して反強磁性と強磁性に振動する層間交換結合を示す．この ような振動性交換層間結合はホイスラー合金においては $\mathrm{Co}_{2}$ $\mathrm{MnSi} / \mathrm{Cr} / \mathrm{Co}_{2} \mathrm{MnSi} 3$ 層膜に抢ける $90^{\circ}$ 結合 $(\mathrm{Cr}$ スペーサー層 を介して 2 つの $\mathrm{Co}_{2} \mathrm{MnSi}$ 層の磁化が直行するように結合す る) (48) といった一般的にはむしろ特殊なものが知られていた が, $\mathrm{Co} / \mathrm{Cu} / \mathrm{Co}$ などの従来材料系の多く(46)にみられる反強 磁性結合については, CFAS/Ag/CFASに打観測が初 めてである.

図10(b)に反強磁性的に層間交換結合した CFAS (4 nm)/
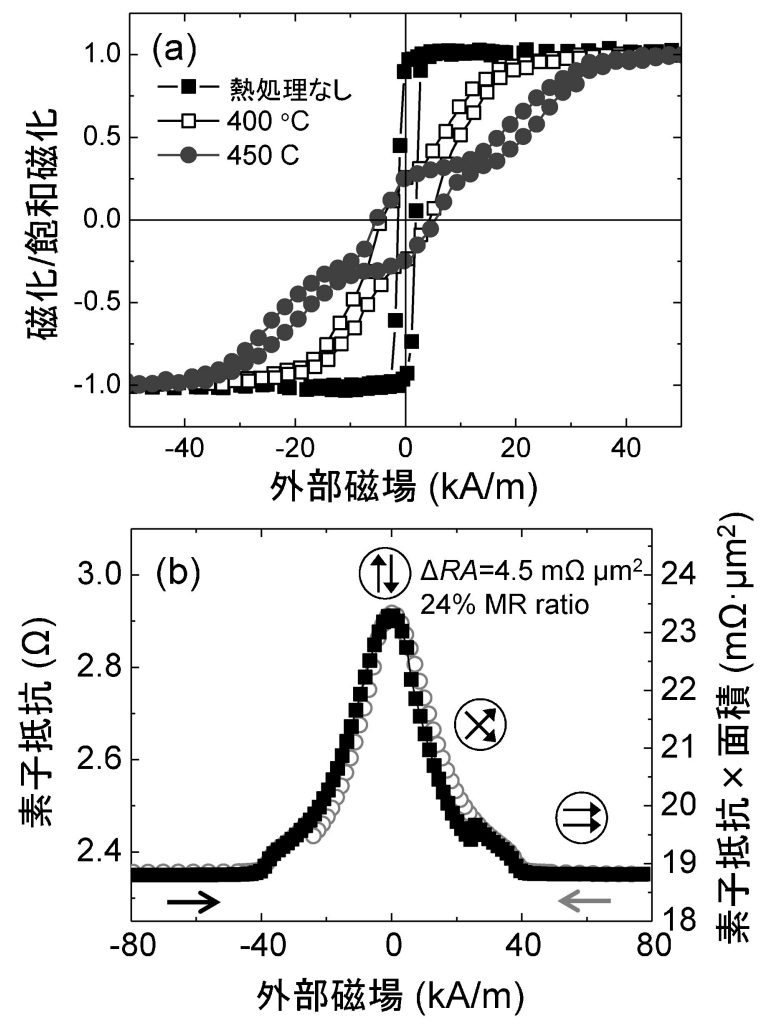

図10 (a) CFAS (5 nm)/ Ag (2 nm)/CFAS (3 nm) 積層膜にお ける磁化曲線. 熱処理された試料においてのみ反強磁性層間交 換結合があわられる。（b) CFAS $(4 \mathrm{~nm}) / \mathrm{Ag}(2 \mathrm{~nm}) / \mathrm{CFAS}(4$ $\mathrm{nm})$ 反強磁性結合膜にお打る CPP-GMR 曲線. 2 つの自由層 の磁化の回転により, 外部磁場に対して連続的に抵抗が変化す る.
$\mathrm{Ag}(2 \mathrm{~nm}) / \mathrm{CFAS}$ (4 nm) エピタキシャル 3 層膜の直径 100 $\mathrm{nm}$ の円形素子における CPP-GMR 曲線を示す. スピンバ ルブ素子と異なり, 磁性層が反強磁性的に結合している場 合, 両方の磁化が外部磁場の変化に対し次第に回転するた め, 素子の抵抗が連続的に変化する. このような抵抗の線形 な磁場応答は再生センサーに必要な特性である。 また, 前章 で述べたようにCFAS と Agの組み合わせにより, 室温で $\Delta R A=4.5 \mathrm{~m} \Omega \cdot \mu \mathrm{m}^{2}, \mathrm{MR}$ 比 $24 \%$ と比較的大きな $\mathrm{CPP}-\mathrm{GMR}$ を示す. また下地層, キャップ層を除いたセンサー部分の厚 さはわずか $10 \mathrm{~nm}$ と, スピンバルブ素子の膜厚の半分以下 であり, 再生センサーとして用いた場合, 高いビット分解能 が得られるだろう。このことからホイスラー合金を用いた 3 層膜 CPP-GMR 素子が超高密度 HDD の再生センサーの候 補として期待される.

\section{(2) 面内スピンバルブ}

従来のスピンバルブや上記の 3 層膜センサーでは, 強磁 性体と非磁性体 (TMR 素子では絶縁体) からなる多層膜構造 に電流を流し, その磁気抵抗効果により磁気ビットの情報を 再生するものである．これに対して 2000 年前半に Jedema らにより考案された面内スピンバルブ(Lateral Spin Valve,

以下 LSV 素子) (49)を用いたセンサー(50)では，図11に示すよ うに CPP-GMR 素子を面内に展開したような素子になって おり, 電流により強磁性体から非磁性体にスピンを注入する 部分と, 磁気ビットを読久取る部分が分離されている，その ため, シールド間ギャップに収納すべき膜構成要素は, 基本 的に強磁性体と非磁性体のそれぞれ 1 層ずつでよく, 超高 ビット分解能の達成が期待できる. また, 強磁性層を 2 層 もつスピンバルブおよび 3 層センサーに比べ, 強磁性層を 厚く設計できるため，熱マグノイズの低減も期待できる.

我々は高スピン分極ホイスラー合金 $\mathrm{Co}_{2} \mathrm{Fe}\left(\mathrm{Ga}_{0.5} \mathrm{Ge}_{0.5}\right)$ (CFGG)を用いた LSV 素子を作製し，そのスピン蓄積信号 を評価した ${ }^{(51)}$ 。図12(a)に作製した LSV 素子の SEM 像を

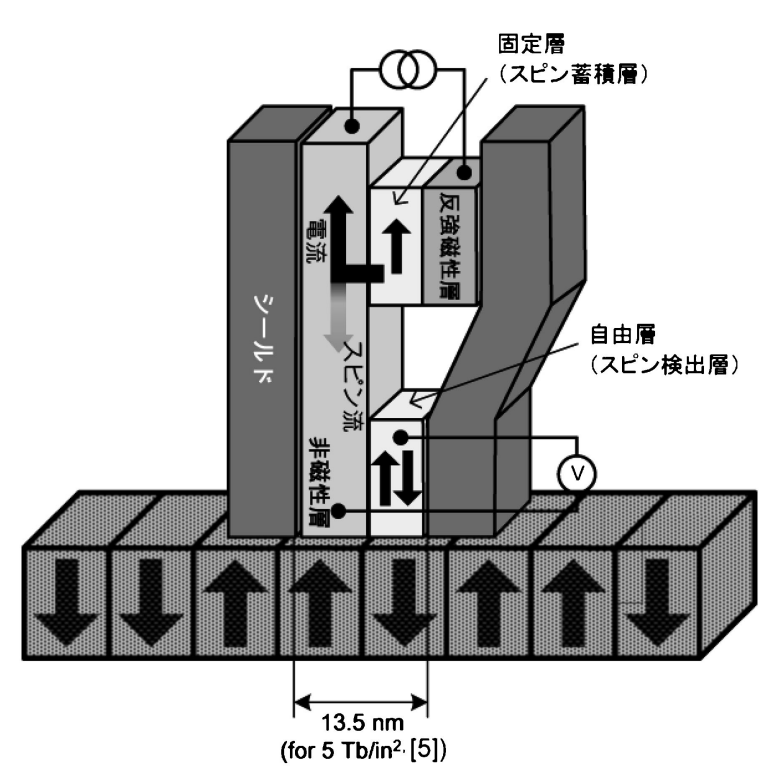

図11 面内スピンバルブを用いた再生センサーの模式図. 
示す。スピン分極電流は CFGG1 細線から $\mathrm{Cu}$ 細線へ注入さ れ，電荷の流れを伴わないスピン流が $\mathrm{Cu}$ 細線中を CFGG2 細線の方へ向かって拡散する. CFGG2 細線と $\mathrm{Cu}$ 細線の電 圧を測定することにより $\mathrm{CFGG} 2 / \mathrm{Cu}$ 界面でのスピン蓄積量 の情報を得ることができる。図 12 (b)に CFGG2 細線と $\mathrm{Cu}$ 細線間の電圧の磁場に対する変化を示す. 室温で $12.8 \mathrm{~m} \Omega$ のスピン蓄積信号が得られている。この值は現在までに報告 されているオールメタルの LSV では最大の值であり， $\mathrm{NiFe}$ 合金(パーマロイ，Py) と Cuを用いた LSVに抢ける 0.72 $\mathrm{m} \Omega$ に比べて圧倒的に大きい(図 12 (b) 挿入図)。スピン蓄積 信号は CFGG 細線間の距離の増加に対して指数関数的に減

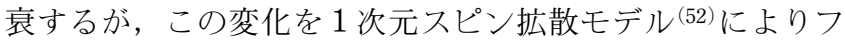

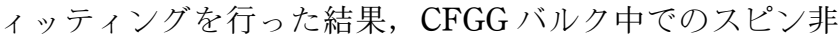
対称性は $0.79, \mathrm{CFGG} / \mathrm{Cu}$ 界面でのスピン非対称性は 0.28 と 見積もられた。この值は前述の CPP-GMR 素子に抢けるバ ルクのスピン非対称性 $(\beta)$ の值とよい一致を示す。本素子で は，最大 $0.07 \mathrm{mV}$ の出力が得られているが，実用には $1 \mathrm{mV}$ 以上の出力が必要とされている。 $\mathrm{CoFeB}$ と $\mathrm{MgO}$ を用いた トンネル型の LSV 素子では $0.8 \mathrm{mV}$ の出力が実現されてい るものの ${ }^{(53)}$ ，前述のように超高密度 HDD の再生センサー には素子の抵抗が小さいことが重要であるため, 抵抗の小さ いオールメタル LSV 素子を用いてさらなる出力の増加が必 要である．熱処理や素子作製プロセスの検討により，ホイス
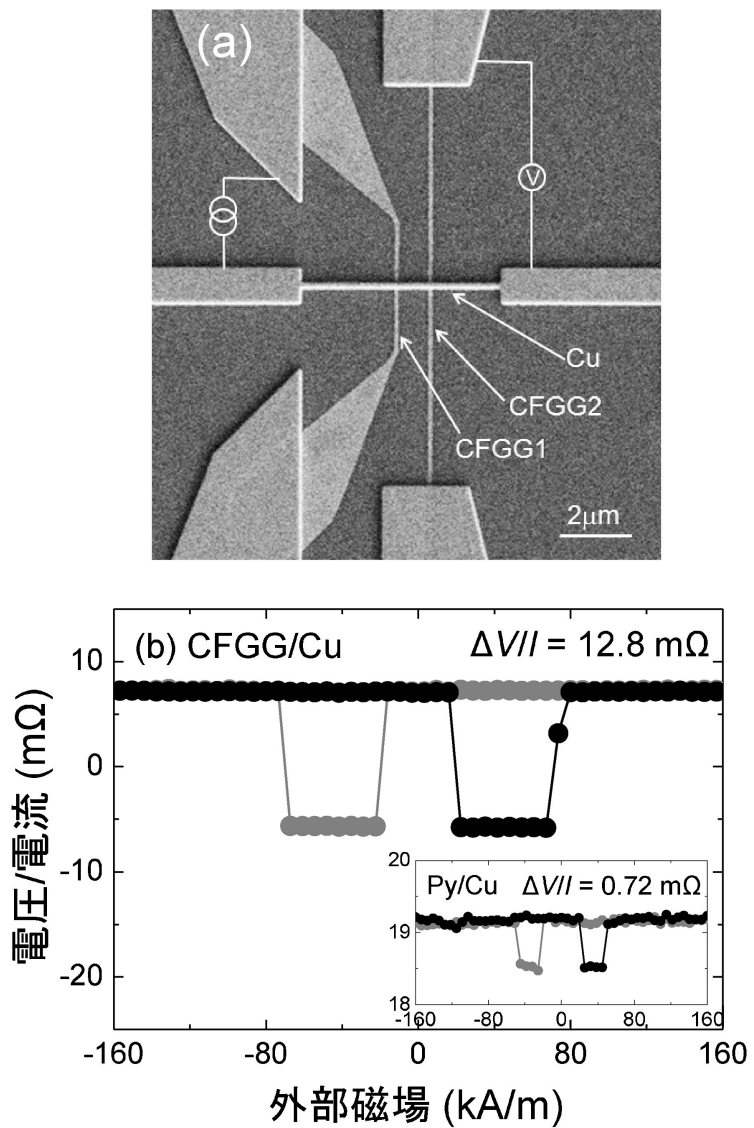

図12 (a) CFGG と $\mathrm{Cu}$ の細線によって構成された面内スピン バルブの SEM 像. (b) $\mathrm{CFGG} / \mathrm{Cu}$ 面内スピンバルブの室温に おけるスピン蓄積信号. 挿入図は $\mathrm{NiFe}$ 合金(パーマロイ, $\mathrm{Py}$ ) と $\mathrm{Cu}$ からなる面内スピンバルブのスピン蓄積信号.
ラー合金から注入されるスピン流のスピン分極率を増加させ ること，および CPP-GMR の実験から実証されたホイスラ 一合金と Ag の高い界面スピン非対称性を利用することによ り，オールメタル LSV 素子を用いて，さらに高いスピン蓄 積信号を実現することが可能であると考えられる.

\section{7. ま と め}

$2 \mathrm{Tbit} / \mathrm{in}^{2}$ を超える超高記録密度 HDD の実現には，記録 媒体ならびに再生へッドに打いて既存材料を越える技術革新 が必須となる。本稿では次世代の再生へッド用磁気センサー の有力候補である CPP-GMR について述べたが，ホイスラ 一合金高スピン分極材料の登場によって，CoFe や $\mathrm{NiFe} と$ いった従来の磁性材料の10倍以上の磁気抵抗を得ることが できるようになった。図 2 に現在までに報告されている CPP-GMR のデータをプロットした。ここからわかるよう に，いまだ $2 \mathrm{Tbit} / \mathrm{in}^{2}$ の記録密度に対応するセンサーとして 適用可能な $R A$ と $\mathrm{MR}$ 比の值を達成した $\mathrm{CPP}-\mathrm{GMR}$ 素子の 報告はなく，さらなる材料の改善が必要である。なた，本稿 では単結晶基板上に成長させたエピタキシャル膜を用いたス ピンバルブ， 3 層センサー，抢よび面内スピンバルブについ て紹介したが，実際の再生センサーの製造には，さまざまな 制約から多結晶薄膜を使うことが避けられない，単結晶膜膜 と異なり多結晶薄膜の場合，熱処理による結晶粒成長や粒界 拡散が問題になるだろう。一方で，これらを利用したホイス ラ一合金膜の化学規則度・磁気特性の制御といった新たな側 面が予想されることから，更なる研究の進展が期待される.

本研究は, 物質・材料研究機構 磁性材料ユニットの葛西 伸哉博士, 介川裕章博士，林将光博士，三谷誠司博士，筑波 大学大学院生の長谷直基博士, Hari Srinivas Goripati 氏と の共同研究をまとめたものです、本稿で紹介した研究は科研 費基盤研究 (A) 22246091括よびJST「さきがけ」の部分的 な支援により実施されました。

\section{文献}

（1）一般社団法人 電子情報技術産業協会 ウェブサイトより http://www.jeita.or.jp/japanese/index.html

（2）東芝ニュースリリース 2011 年 8 月 2 日 http://www.toshiba. co.jp/about/press/2011 08/pr j0201.htm

（3）岩崎仁志 : 金属, 77(2007), 959-963.

( 4 ) B. Dieny, V. S. Speriosu, S. S. P. Parkin, B. A. Gurney, D. R. Wilhoit and D. Mauri: Phys. Rev. B (R), 43(1991), 12971300.

( 5 ) M. Takagishi, K. Yamada, H. Iwasaki, H. N. Fuke and S Hashimoto: IEEE Trans. Magn., 46(2010), 2086-2089.

( 6 ) S. S. P. Parkin, C. Kaiser, A. Panchula, P. M. Rice, B. Hughes, M. Samant and S.-H. Yang: Nat. Mater., 3(2004), 862-867.

( 7 ) S. Yuasa, T. Nagahama, A. Fukushima, Y. Suzuki and K. Ando: Nat. Mater., 3(2004), 868-871.

( 8 ) D. D. Djayaprawira, K. Tsunekawa, M. Nagai, H. Maehara, S. Yamagata, N. Watanabe, S. Yuasa, Y. Suzuki and K. Ando: Appl. Phys. Lett., 86(2005), 092502.

( 9 ) H. Maehara, K. Nishimura, Y. Nagamine, K. Tsunekawa, T. Seki, H. Kubota, A. Fukushima, K. Yakushiji, K. Ando and S. Yuasa: App. Phys. Express, 4(2011), 033002. 
(10) J. R. Childress, M. J. Carey, S. I. Kiselev, J. A. Katine, S. Maat and N. Smith: J. Appl. Phys., 99(2006), 08C305.

(11) J. Bass and W. P. Pratt Jr.: J. Phys. Condens. Matter, 19 (2007), 183201.

（12）今村裕志 : 金属, $77(2007), 982-987$.

(13) T. Valet and A. Fert: Phys. Rev. B, 48 (1993), 7099-7113.

(14) J. Bass and W. P. Pratt Jr.: J. Magn. Magn. Mater., 200 (1999), 274-289.

(15) S. D. Steenwyk, S. Y. Hsu, R. Loloee, J. Bass and W. P. Pratt, Jr.: J. Magn. Magn. Mater., 170(1997), L1-L6.

(16) T. M. Nakatani, T. Furubayashi, S. Kasai, H. Sukegawa, Y. K. Takahashi, S. Mitani and K. Hono: Appl. Phys. Lett., 96 (2010), 212501.

(17) A. Jogo, K. Nagasaka, T. Ibusuki, Y. Shimizu, A. Tanaka and H. Ohshima: J. Magn. Magn, Mater., 309(2007), 80-86.

(18) S. Maat, M. J. Carey and J. R. Childress: J. Appl. Phys., 101 (2007), 093905.

(19) S. Maat, M. J. Carey and J. R. Childress: Appl. Phys. Lett., 93 (2008), 143505

(20) S. Ishida, S. Akazawa, Y. Kubo and J. Ishida, J. Phys. F: Met. Phys., 12(1982), 1111-1122. S. Ishida, S. Fujii, S. Kashiwagi and S. Asano: J. Phys. Soc. Jpn., 64(1995), 2152-2157.

(21) I. Galanakis, P. H. Dederichs and N. Papanikolaou, Phys. Rev. B, 66(2002), 174429.

(22) Y. Sakuraba, J. Nakata, M. Oogane, H. Kubota, Y. Ando, A. Sakuma and T. Miyazaki: Jpn. J. Appl. Phys., 44(2005), L1100-L1102.

(23) Y. Sakuraba, M. Hattori, M. Oogane, Y. Ando, H. Kato, Y. Ando, A. Sakuma, T. Miyazaki and H. Kubota: Appl. Phys. Lett., 88(2006), 192508.

(24) S. Picozzi, A. Continenza and A. J. Freeman: Phys. Rev. B, 69 (2004), 094423.

(25) Y. Miura, K. Nagao and M. Shirai: Phys. Rev. B, 69(2004), 144413.

(26) M. J. Carey, S. Maat, S. Chandrashekariaih, J. A. Katine, W. Chen, B. York and J. R. Childress: J. Appl. Phys., 109(2011), 093912.

（27）高橋有紀子, A. Rajanikanth, 中谷友也, 宝野和博 : まてり あ, 47 (2008), 406-412.

(28) N. Tezuka, N, Ikeda, M. Miyazaki, S. Sugimoto and K. Inomata: Appl. Phys. Lett., 89(2006), 112514.

(29) N. Tezuka, N, Ikeda, S. Sugimoto and K. Inomata: Appl. Phys. Lett., 89(2006), 252508.

(30) T. Furubayashi, K. Kodama, H. Sukegawa, Y. K. Takahashi, K. Inomata and K. Hono: J. Appl. Phys., 93 (2008), 122507.

(31) T. Furubayashi, K. Kodama, T. M. Nakatani, H. Sukegawa, Y. K. Takahashi, K. Inomata and K. Hono: J. Appl. Phys., 107 (2010), 113917.

（32）高橋有紀子, 古林孝夫, 大久保忠勝, 宝野和博 : まてりあ, 49(2010), 580-584.

(33) T. Iwase, Y. Sakuraba, S. Bosu, K. Saito, S. Mitani and K. Takanashi: Appl. Phys. Express, 2(2009), 063003.

(34) T. M. Nakatani. T. Furubayashi and K. Hono: J. Appl. Phys., 109 (2011), 07B724

(35) T. M. Nakatani, N. Hase, H. S. Goripati, Y. K. Takahashi, T. Furubayashi and K. Hono: IEEE Trans. Magn., 48(2012), 1751-1757.

(36) Y. Sakuraba, K. Izumi, T. Iwase, S. Bosu, K. Saito and K. Takanashi: Phys. Rev. B, 82(2010), 094444.

(37) Y. Miura, K. Futatsukawa, S. Nakajima, K. Abe and M. Shirai: Phys. Rev. B, 84(2011), 134432.

(38) H. S. Goripati, T. Furubayashi, S. V. Karthik, T. M. Nakatani, Y. K. Takahashi and K. Hono: J. Appl. Phys., 109(2011), 043901.

(39) N. Hase, B. S. D. Ch. S. Varaprasad, Y. K. Takahashi and K.

Hono: to be published.

(40) Y. K. Takahashi, A. Srinivasan, B. Varaprasad, A. Rajanikanth, N. Hase, T. M. Nakatani, S. Kasai, T. Furubayashi and K. Hono: Appl. Phys. Lett., 98(2011), 152501.

(41) B. S. D. Ch. S. Varaprasad, A. Srinivasan, Y. K. Takahashi, M. Hayashi, A. Rajanikanth and K. Hono: Acta Mater., 60(2012), 6257-6265.

(42) T. M. Nakatani, A. Rajanikanth, Z. Gercsi, Y. K. Takahashi, K. Inomata and K. Hono: J. Appl. Phys., 102(2007), 033916.

(43) H. S. Goripati, T. Furubayashi, Y. K. Takahashi and K. Hono: J. Appl. Phys., 113(2013), 043901.

(44) R. Lamberton, M. Seigler, K. Pelhos, H. Zhou, M. McCurry, M. Ormston, G. Yi, G. McClean, T. McLaughlin, P. Kolbo, O. Heininen, V. Sapozhnikov and S. Mao: IEEE Trans. Magn., 43 (2007), 645-650.

(45) R. Grünberg, R. Schreider, Y. Peng, M. B. Brodsky and H. Sowers: Phys. Rev. Lett., 57 (1986), 2442-2445. G. Binasch, P. Grünberg, F. Saurenbach and W. Zinn: Phys. Rev. B, 39 (1989), 4828-4830.

(46) S. S. P. Parkin, N. More and K. P. Roche: Phys. Rev. Lett., 64 (1990), 2304-2307. S. S. P. Parkin: ibid, 67 (1991), 35983601.

(47) T. M. Nakatani, S. Mitani, T. Furubayashi and K. Hono: Appl. Phys. Lett., 99 (2011), 182505.

(48) H. Wang, A. Sato, K. Saito, S. Mitani, K. Takanashi and K. Yakushiji: Appl. Phys. Lett., 90(2007), 142510.

(49) F. J. Jedema, A. T. Filip and B. J. van Wees: Nature, 410 (2001) 345-348. F. J. Jedema, H. B. Heersche, A. T. Filip, J. J. A. Baselmans and B. J. van Wees: Nature, 416(2002), 713716.

(50) T. D. Boone, Jr., B. A. Gurney and N. Simth: U. S. patent US2010/0296202, Nov. 25, (2010). K. Ito and H. Takahashi: Japanese Patent Publication No. 2004-342241. Dec. 2, (2004).

(51) Y. K. Takanashi, S. Kasai, S. Hirayama, S. Mitani and K. Hono: Appl. Phys. Lett., 100(2012), 052405.

(52) S. Takahashi and S. Maekawa: Phys. Rev. B, 67(2003), 052409 .

(53) M. Yamada, D. Sato, N. Yoshida, M. Sato, K. Meguro and S. Ogawa: The 23rd Magnetic Recording Conference (TMRC2012), D2, (2012), IEEE Trans. Magn., 49(2013), $713-717$.

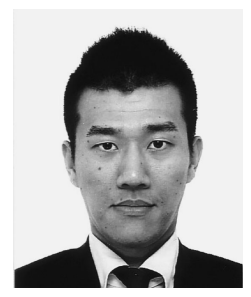

中谷友也

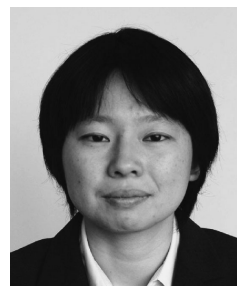

高橋有紀子

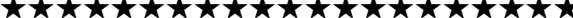
2011年 筑波大学大学院数理物質科学研究科物質. 材料工学専攻博士後期課程修了博士 (工学) 2010 年-2012年 日本学術振興会特別研究員 (DC2, PD)

2012年 4 月-5 月 物質・材料研究機構 ポスドク研 究員

2012年 6 月より HGST, a Western Digital company, San Jose Research Center, Research Engineer 専門分野：スピントロニクス材料，磁気記録 (〕現在もHDD メーカーにて再生センサーの材料開発 に従事しています。

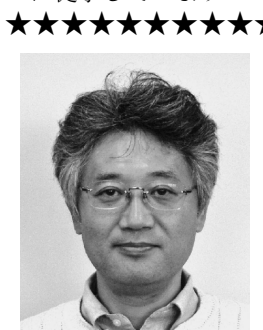

古林孝夫

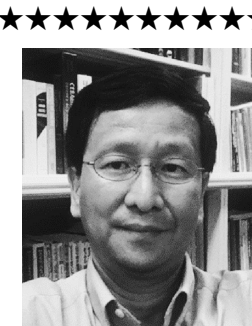

宝野和博 